\title{
Adenoid cystic carcinoma of the breast: prevalence, diagnostic criteria, and histogenesis
}

\author{
P. P. ANTHONY AND P. D. JAMES ${ }^{1}$ \\ From the Bland-Sutton Institute of Pathology, Middlesex Hospital Medical School, London WI
}

SYNOPSIS Three cases of adenoid cystic carcinoma have been identified in a 10-year review of 2686 cases of breast carcinoma. The criteria necessary for diagnosis have been reviewed with particular reference to cribriform intraduct carcinoma and adenocarcinoma of the breast with a small, dark, 'basaloid'-cell pattern. The most important single diagnostic criterion of adenoid cystic carcinoma is a biphasic cellular pattern which may be aided by the demonstration of two types of mucinstromal acid mucopolysaccharide and ductal neutral mucopolysaccharide. This tumour most frequently presents as a painful or tender mass near the areola, and it carries a uniquely favourable prognosis when compared with similar tumours elsewhere in the body. Actomyosin has been demonstrated in all three tumours by an immunofluorescent method, and this supports a predominantly myoepithelial origin.

Adenoid cystic carcinoma (adenocystic carcinoma, cylindroma, basaloid carcinoma) is best known as a tumour of salivary glands though it infrequently also occurs at other sites in the body-the tracheobronchial tree, nasopharynx, maxillary sinus, uterine cervix, and the skin. The tumour is characteristically made up of small, dark, ovoid cells with a sieve-like or cribriform pattern of growth, and small cysts may form. These cells resemble the basal cells of epithelial surfaces or myoepithelial cells. In addition, small, duct-like structures are also seen. The well-differentiated cytological features belie a tendency to infiltrate, recur, and metastasize. The prognosis is generally poor (Evans and Cruickshank, 1970).

Galloway et al (1966) reported nine cases of adenoid cystic carcinoma occurring in the breast, none of which recurred or metastasized after mastectomy. Since that time numerous reports have appeared, mainly from the United States and the European continent, which have confirmed the excellent prognosis at this site. These have been summarized in table I. Single case reports have been omitted except those which illustrate some unusual feature. The rarity of this tumour in the breast and the difficulty of distinguishing it from other lesions, notably intraduct carcinoma, sclerosing adenosis,

Present address: General Hospital, Nottingham

Received for publication 10 February 1975. and epitheliosis, have been repeatedly emphasized (Cavanzo and Taylor, 1969; Friedman and Oberman, 1970; Lusted, 1970). Histogenesis remains doubtful, and ultrastructural studies have been inconclusive (Koss et al, 1970; Woyke et al, 1970).

Recent interest in adenoid cystic carcinoma of the breast and the diagnostic problems associated with it have stimulated us to review our own material of breast tumours over a 10 -year period in order to assess prevalence and to review criteria for diagnosis.

We have also undertaken an investigation of the possible myoepithelial origin of this tumour with the use of immunofluorescent techniques.

\section{Materials and Methods}

During the 10 years from 1961 to 1970 some 2686 cases of breast carcinoma were seen at this institute. All the sections were reviewed in a search for adenoid cystic carcinoma and tumours closely resembling it. The term adenoid cystic carcinoma is the one recommended by the World Health Organization in preference to other synonyms (Thackray and Sobin, 1972). Twenty-six were found in which this diagnosis might have been considered by a reasonably experienced pathologist. The blocks from these cases were re-cut and stained with haematoxylin-eosin, periodic acid-Schiff (PAS) reaction with and without diastase, alcian blue at pH 2.6, combined alcian blue-PAS (Mowry, 1956) 


\begin{tabular}{|c|c|c|c|c|}
\hline Reference & No. of Cases & $\begin{array}{l}\text { Age Range } \\
\text { (av.) }\end{array}$ & Se.x & Duration of Symptoms \\
\hline Nayer (1957) & 1 & 39 & $\mathbf{F}$ & $1 \mathrm{yr}$ \\
\hline O’Kell (1964) & 3 & $47-76(59)$ & $\mathbf{F}$ & $8 \mathrm{~d}-6 \mathrm{mth}$ \\
\hline Galloway et al (1966) & $y$ & $44-80(53)$ & $\mathbf{F}$ & $2 \mathrm{~d}-15 \mathrm{yr}$ \\
\hline $\begin{array}{l}\text { Wilson and Spell (1967) } \\
\text { Cavanzo and Taylor (1969) }\end{array}$ & $\begin{array}{r}1 \\
21\end{array}$ & $\begin{array}{l}54 \\
31-69(50)\end{array}$ & $\begin{array}{l}F \\
F\end{array}$ & $\begin{array}{l}3 \mathrm{mth} \\
\text { Few weeks-many years }\end{array}$ \\
\hline Elsner (1970) & 7 & $38-80(50)$ & $\mathrm{F}$ & $2 \mathrm{mth}-12 \mathrm{yr}$ \\
\hline Friedman and Oberman (1970) & 5 & $53-76(63)$ & $F$ & $7 \mathrm{~d}-6 \mathrm{mth}$ \\
\hline $\begin{array}{l}\text { Koss et al (1970) } \\
\text { Lusted (1970) }\end{array}$ & $\begin{array}{l}5 \\
4\end{array}$ & $\begin{array}{l}41-77 \\
42-65(52)\end{array}$ & $\begin{array}{l}\mathrm{F} \\
\mathrm{F}\end{array}$ & $2 \mathrm{wk}-11 \mathrm{yr}$ \\
\hline $\begin{array}{l}\text { Woyke et al (1970) } \\
\text { Hopkins and Tullis (1972) } \\
\text { Verani and van der Bel-Kahn (1973) }\end{array}$ & $\begin{array}{l}1 \\
3 \\
2\end{array}$ & $\begin{array}{l}33-53(43) \\
63-78(52)\end{array}$ & $\begin{array}{l}\mathbf{M} \\
\mathbf{F} \\
\mathbf{F} \\
\mathbf{M}\end{array}$ & $\begin{array}{l}3-5 \mathrm{mth} \\
6 \mathrm{wk}-10 \mathrm{yr}\end{array}$ \\
\hline
\end{tabular}

Table I Adenoid cystic carcinoma of the breast: a summary of salient features in 62 cases

and phosphotungstic acid-haematoxylin. A study of this material resulted in the identification of three cases of adenoid cystic carcinoma, 19 cases of cribriform intraduct carcinoma, and four cases of 'basaloid' tumour. We have not experienced any difficulty in distinguishing well-differentiated ductal adenocarcinoma, sclerosing adenosis or epitheliosis from adenoid cystic carcinoma.

Specific antiserum to actomyosin prepared from calf aorta was raised in rabbits and supplied to us by Professor J. F. Hampe, Pathological-Anatomical Laboratory, Amsterdam, The Netherlands. This was applied to deparaffinized sections with an indirect immunofluorescent technique utilizing antirabbit immunoglobulin raised in sheep. The results were viewed in a Leitz $O_{1}$ tholux microscope with appropriate filters, and the identity of the structures seen was checked by phase contrast. All three adenocystic carcinomas were subjected to immunofluorescence microscopy together with two cases each of intraduct carcinoma and of 'basaloid' tumour. Sections from normal myocaridum and skeletal muscle, which had been stored for approximately the same period as the test cases, were used as controls.

\section{Results}

ADENOID CYSTIC CARCINOMA

Brief clinical details are summarized in table II for comparison with table I. There are no conclusions to be drawn from three cases, but they do fall into the overall pattern of cases summarized in table I. In two patients the tumour arose in the nipple area and was tender. All three tumours were rounded and fairly well defined. The cut surface was cystic in one case. All three patients are alive and well and free of recurrence nine, six, and three years later. One patient (case 3) had had an 'ordinary' adenocarcinoma of the contralateral breast removed one year previously.

\section{Histology}

All three tumours showed a lobulated pattern of growth with finger-like extensions into surrounding tissues (fig 1). A Swiss cheese or sieve-like cribriform pattern was invariably present but some of the lobules were solid or reticular in structure. Larger 'cysts' were present in one case. Perineural infiltration was not seen.

The cellular component was of two types. The

\begin{tabular}{|c|c|c|c|c|c|c|c|c|}
\hline Case & Age & Sex & $\begin{array}{l}\text { Duration } \\
\text { (weeks) }\end{array}$ & Presentation & Site & $\begin{array}{l}\text { Size } \\
(\mathrm{cm})\end{array}$ & Treatmert & Course \\
\hline 1 & 61 & $\mathbf{F}$ & 4 & Tender mass & Periareolar & $3 \times 1$ & Radical mastectomy & Alive and well 6 yr later \\
\hline 2 & 38 & $\mathbf{F}$ & 8 & Mass & $\begin{array}{l}\text { Upper outer } \\
\text { quadrant }\end{array}$ & 2 & $\begin{array}{l}\text { Local excision followed by } \\
\text { radiotherapy }\end{array}$ & Alive and well $9 \mathrm{yr}$ later \\
\hline 3 & 48 & $\mathbf{F}$ & 6 & Tender mass & Lateral to nipple & 2 & Radical mastectomy & Alive and well 3 yr later \\
\hline
\end{tabular}

Table II Brief details of three cases of adenoid cystic carcinoma of the breast 


\begin{tabular}{|c|c|c|c|c|}
\hline Presentation & Site & $\begin{array}{l}\text { Size } \\
(\mathrm{cm})\end{array}$ & Treatment & Course \\
\hline \multirow{4}{*}{$\begin{array}{l}\text { Tender or painful mass in } \\
\text { four cases }\end{array}$} & & & Radical mastectomy & $\begin{array}{l}\text { Dead of disseminated malignant disease } 13 \text { yr later. No } \\
\text { necropsy }\end{array}$ \\
\hline & & 1 & Radical mastectomy & $\begin{array}{l}\text { Two alive and well } 1 \text { yr and } 1 \text { yr } 3 \mathrm{mth} \text { later. One died } \\
\text { of metastases } 3 \frac{1}{2} \text { yr later }\end{array}$ \\
\hline & 4 near areolar & $0 \cdot 6-3$ & Radical mastectomy & All alive and well; four patients up to $7 \frac{1}{2}$ to $15 \mathrm{yr}$ \\
\hline & Near nipple & $2-8$ & Simple mastectomy & Local recurrence $7 \frac{1}{2}$ and $15 \frac{1}{2}$ yr later \\
\hline \multirow[t]{2}{*}{$\begin{array}{l}\text { Mass in breast 'sometimes } \\
\text { tender' }\end{array}$} & & $1-5$ & $\begin{array}{l}\text { Local excision (4) } \\
\text { Simple mastectomy (3) } \\
\text { Radical mastectomy (13) } \\
\text { Unknown (1) }\end{array}$ & $\begin{array}{l}\text { Local recurrence in } 2 \text {; death from unrelated causes in } 2 \text {; } \\
\text { rest alive and well } 2-14 \text { yr later }\end{array}$ \\
\hline & & $1-12$ & $\begin{array}{l}\text { Simple mastectomy (1) } \\
\text { Radical mastectomy (6) }\end{array}$ & $\begin{array}{l}\text { Metastasis to lung in one case after } 0 \text { yr; rest alive and } \\
\text { well 2-14 yr later }\end{array}$ \\
\hline Painful mass in two cases & 3 periareolar & $2-4$ & $\begin{array}{l}\text { Simple mastectomy (4) } \\
\text { Radical mastectomy (1) }\end{array}$ & One died of heart disease; four alive and well $1-4$ yr later \\
\hline Painful mass in one case & & $5-8$ & $\begin{array}{l}\text { Radical mastectomy } \\
\text { Radical mastectomy }\end{array}$ & $\begin{array}{l}\text { Alive and well } 2-10 \text { yr later } \\
\text { One local recurrence after } 22 \frac{1}{2} \text { yr. All alive and well } \\
\text { up to } 39 \text { yr later }\end{array}$ \\
\hline Tender mass in two cases & $\begin{array}{l}2 \text { subareolar } \\
1 \text { subareolar }\end{array}$ & $\begin{array}{l}1 \cdot 8-3 \\
2-3\end{array}$ & $\begin{array}{l}\text { Radical mastectomy } \\
\text { Radical mastectomy }\end{array}$ & $\begin{array}{l}\text { All alive and well } 2-13 \text { yr later } \\
\text { Axillary lymph node metastasis in one; both died of } \\
\text { metastases }\end{array}$ \\
\hline
\end{tabular}

Table I-continued

bulk of these tumours was made up of small, dark cells, 4-8 $\mu \mathrm{m}$ in size, oval or elongated in shape, with regular dense nuclei and scanty cytoplasm. The 'cysts' within the lobules were invariably surrounded by such cells (fig 2 ). In addition, scanty, duct-like structures were also present lined by a single layer of cuboidal cells with paler nuclei and more abundant, finely granular cytoplasm. Though not fully differentiated, these resembled normal breast ductules (fig 3). They were present in all three cases but were found only after prolonged search, usually within smaller masses. Mitoses were rarely seen anywhere in these tumours and necrosis was absent.

The 'cysts' contained loose, fibrillar or mucoid material often with a capillary blood vessel in the centre, and sometimes with peripheral condensation adjacent to surrounding tumour epithelium (fig 2). In some, this process had led to hyalinization either in a lace-like or globular pattern, resembling the pattern seen in a 'mixed' tumour (pleomorphic adenoma) (fig 4). The duct-like structures showed tubular lumina that did not communicate with 'cysts' and were free of fibrillary material, capillaries or hyalin.

\section{Histochemistry}

The contents of the 'cysts' gave a strong positive reaction with alcian blue and were PAS negative in contrast to the contents of the duct-like structures which were weakly positive with alcian blue and strongly positive with PAS. In the combined alcian blue-PAS preparations, the 'cysts' were alcian blue positive and the ducts PAS positive (table III). The PTAH stain failed tn demnnstrate myofibrils though

\begin{tabular}{llll}
\hline Tumour & PAS & Alcian Blue & PAS + Alcian Blue \\
\hline $\begin{array}{c}\text { Adenoid cystic } \\
\text { carcinoma }\end{array}$ & $\begin{array}{l}\text { Ducts }+ \\
\text { 'Cysts' }+\end{array}$ & 'Cysts' $++\begin{array}{l}\text { Ducts PAS }+ \\
\text { 'Cysts' alcian } \\
\text { blue }+\end{array}$ \\
$\begin{array}{c}\text { Cribriform intraduct } \\
\text { carcinoma }\end{array}$ & $\begin{array}{l}\text { Ducts and } \\
\text { 'cysts' }++\end{array}$ & $\begin{array}{l}\text { Ducts and } \\
\text { 'cysts' }+\end{array}$ & $\begin{array}{l}\text { Ducts and cysts } \\
\text { PAS }+ \\
\text { 'Basaloid' tumour }\end{array}$ \\
'Cysts' & 'Cysts' + & $\begin{array}{c}\text { Cysts' alcian } \\
\text { blue }+\end{array}$ \\
\hline
\end{tabular}

Table III Summary of staining reactions for acid and neutral mucopolysaccharides

some scattered granular staining was seen in some areas. The media of small blood vessels stained strongly positive.

\section{Immunofluorescence}

A strong, though scattered cytoplasmic fluorescence was seen in all three tumours, generally in small cell masses (figs 5-6) and was equal in intensity to the reaction given by the smooth muscle media of small blood vessels in the same sections (figs 7-8) and by skeletal muscle and myocardium in the control sections.

CRIBRIFORM INTRADUCT CARCINOMA

Whole tumours or selected areas within them gave rise to differential diagnostic difficulty in 19 such cases. The resemblance to adenoid cystic carcinoma proved, however, to be superficial on detailed examination. Cribriform intraduct carcinomas also formed distinct masses but these were rounded rather than lobulated in outline, and a basement membrane could usually be demonstrated. 


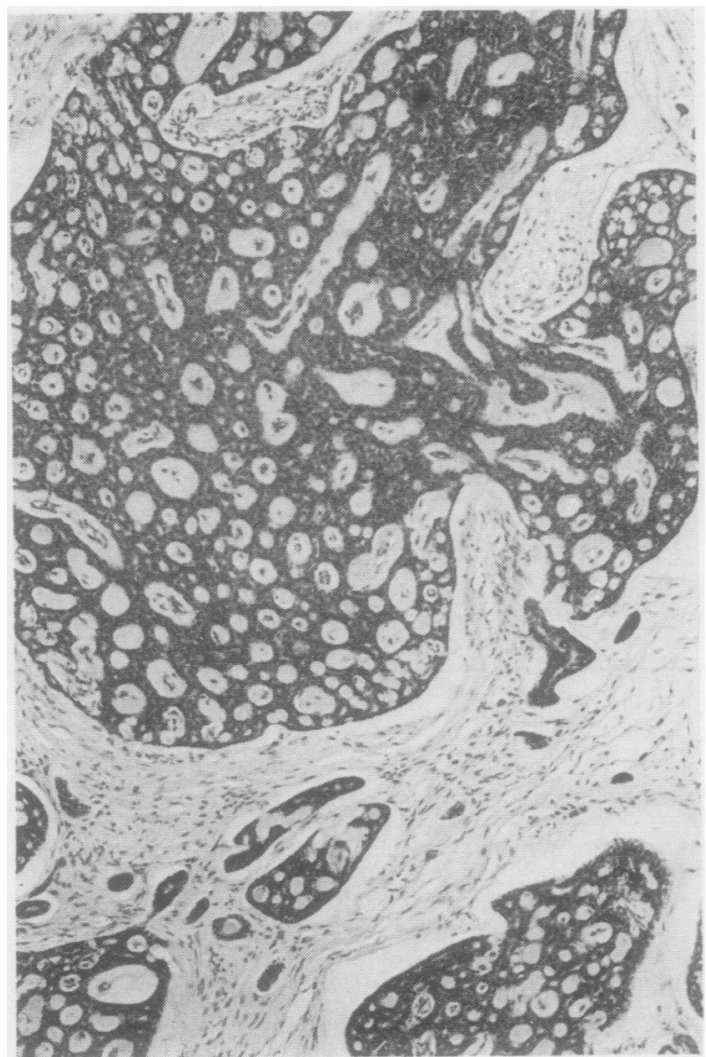

Fig 1

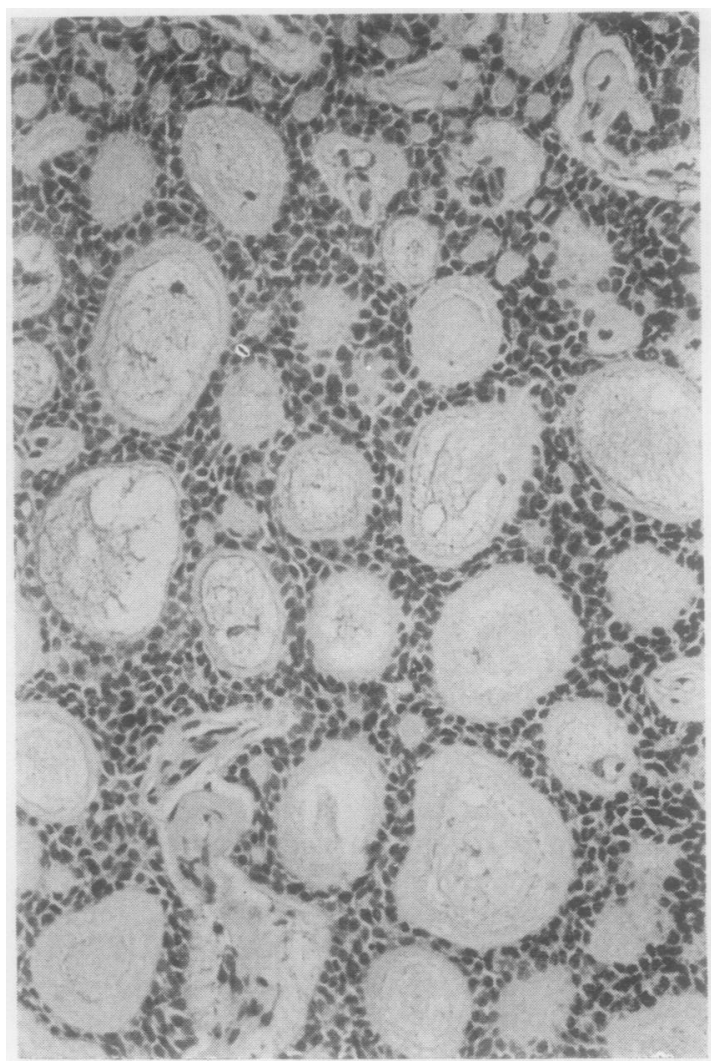

Fig 2

Fig 1 Lobulated masses of adenoid cystic carcinoma of the breast with characteristic 'Swiss cheese' pattern and finger-like extensions into stroma (Haematoxylin-eosin $\times 35$ ).

Fig 2 Small, dark, uniform cells enclosing 'cysts' which contain loose, fibrillar material (Haematoxylin-eosin $\times 85)$

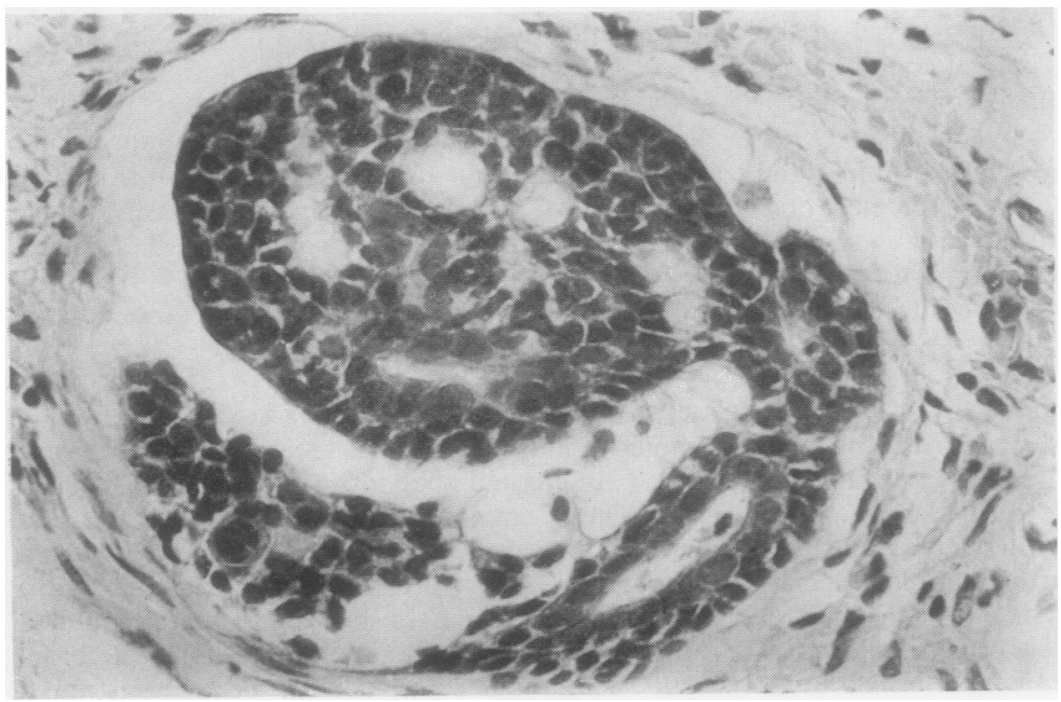

Fig 3 Duct-like structures

(Haematoxylin-eosin $\times 220$ ). 


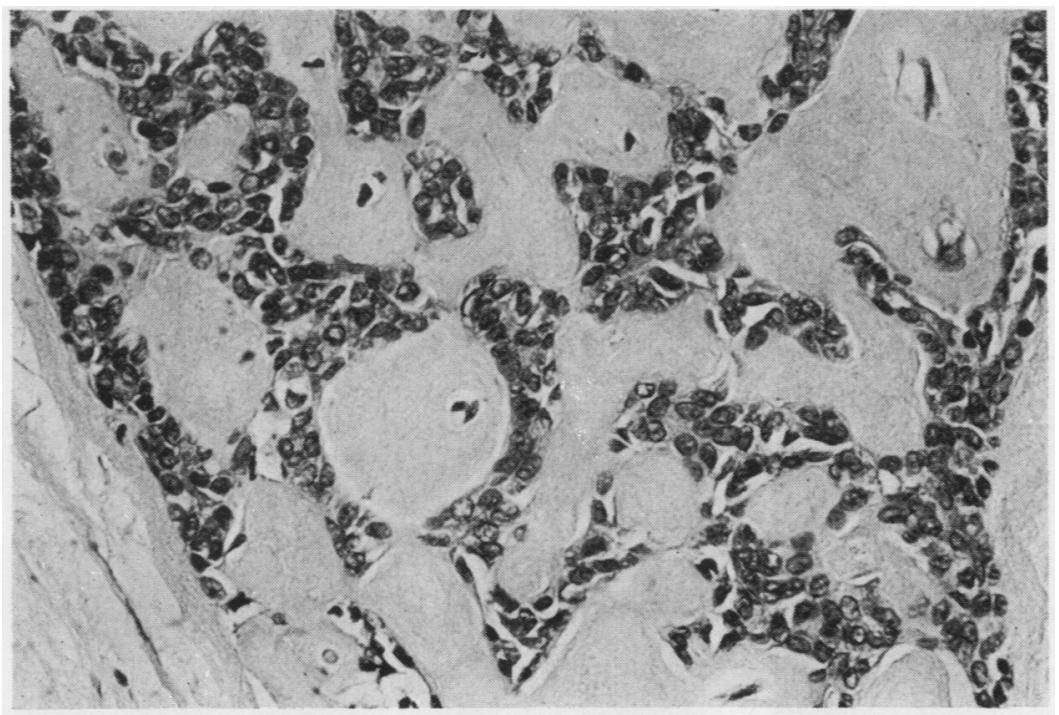

Fig 4 Hyalinization of the stroma within 'cysts' gives rise to pleomorphic adenoma-like pattern (Haematoxylin-eosin $\times 138$ ).

Fig 5 Adenoid cystic carcinoma viewed by phase contrast $(\times 138)$.

Fig 6 Adjacent section stained for actomyosin by immunofuorescence ( $\times 138)$.

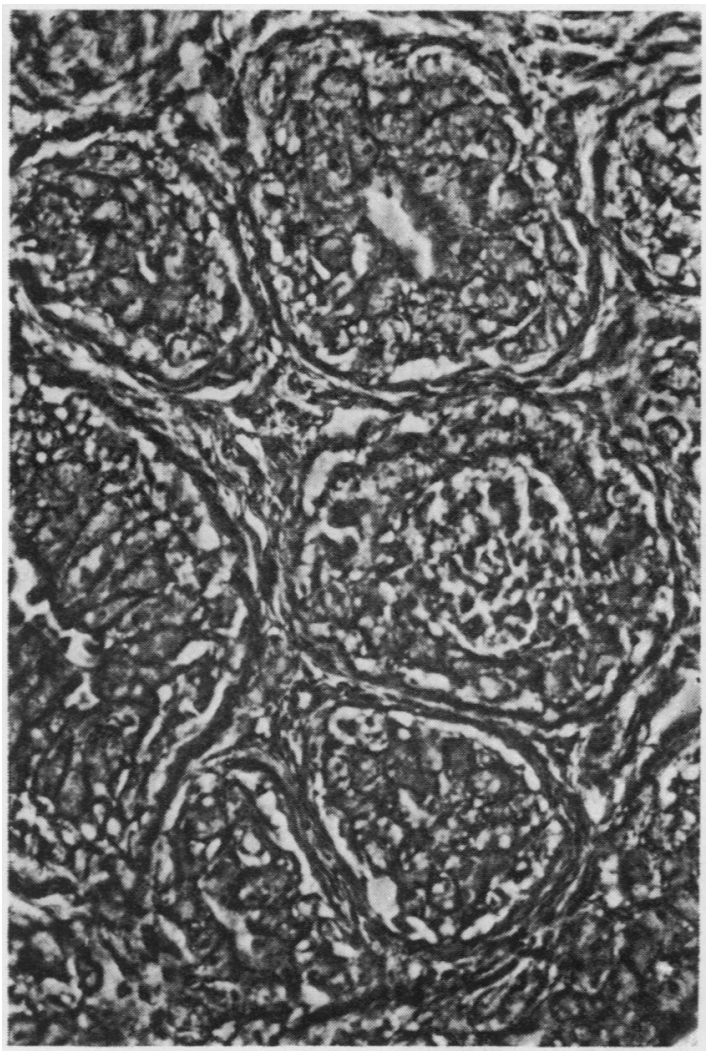

Fig 5

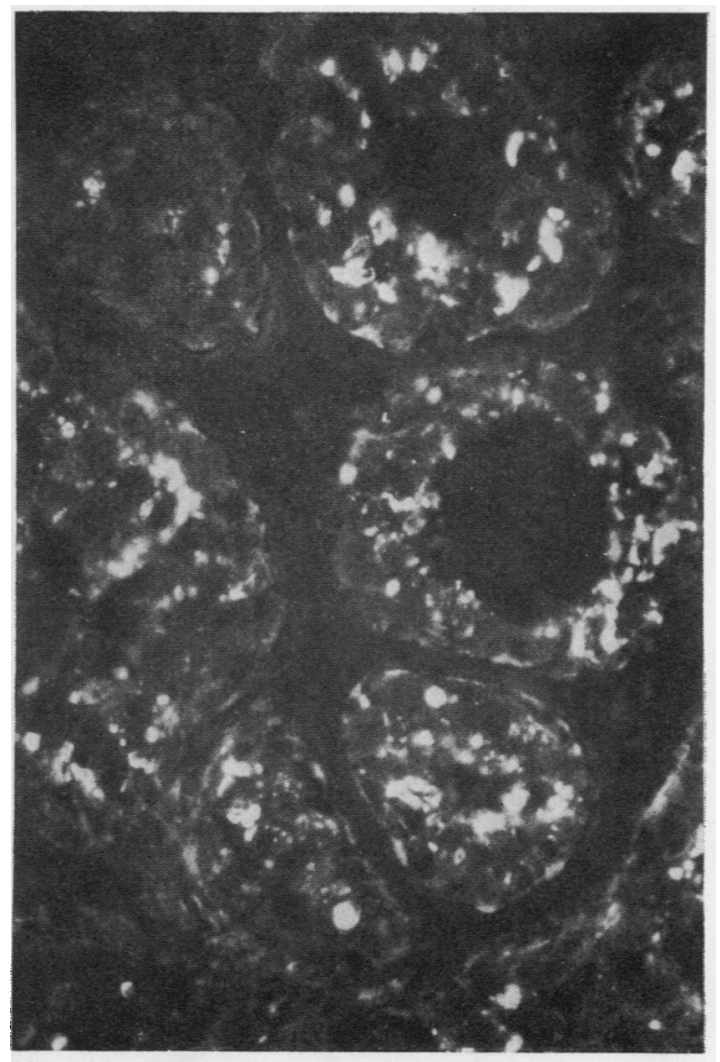

Fig 6 


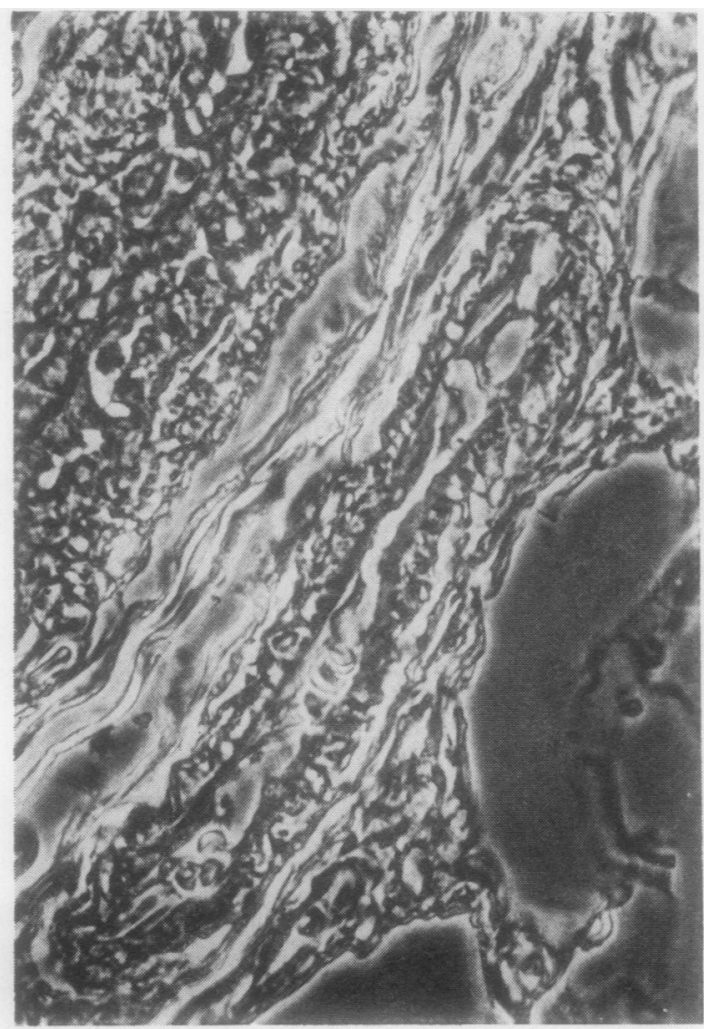

Fig 7

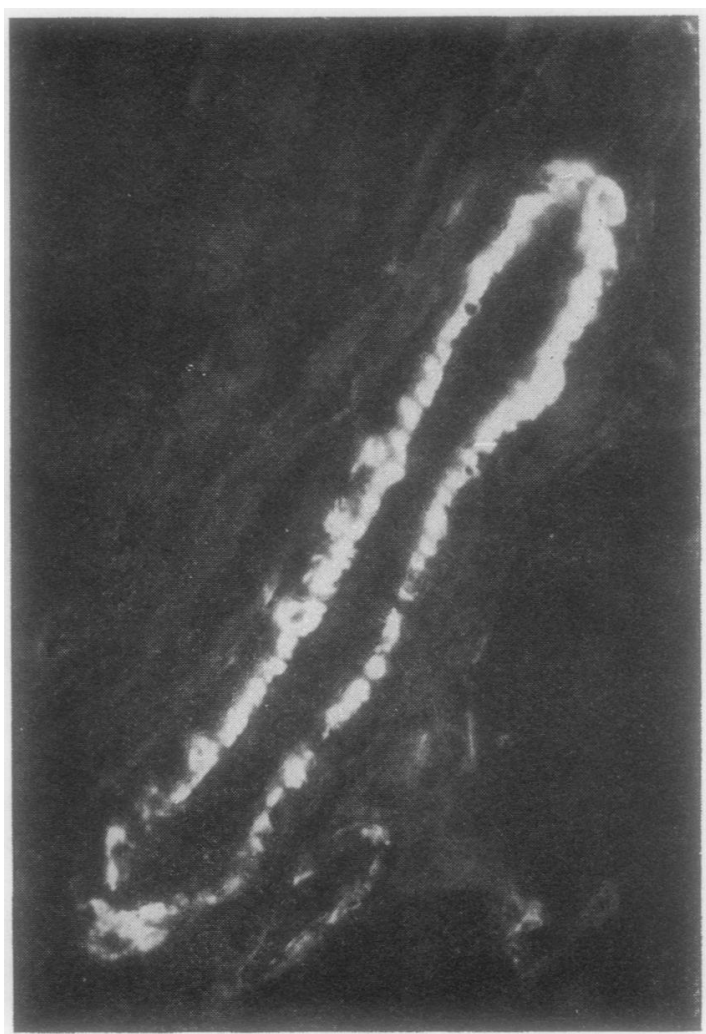

Fig 8

Fig 7 Small blood vessel viewed by phase contrast $(\times 138)$.

Fig 8 Same vessel stained for actomyosin by immunofluorescence $(\times 138)$.

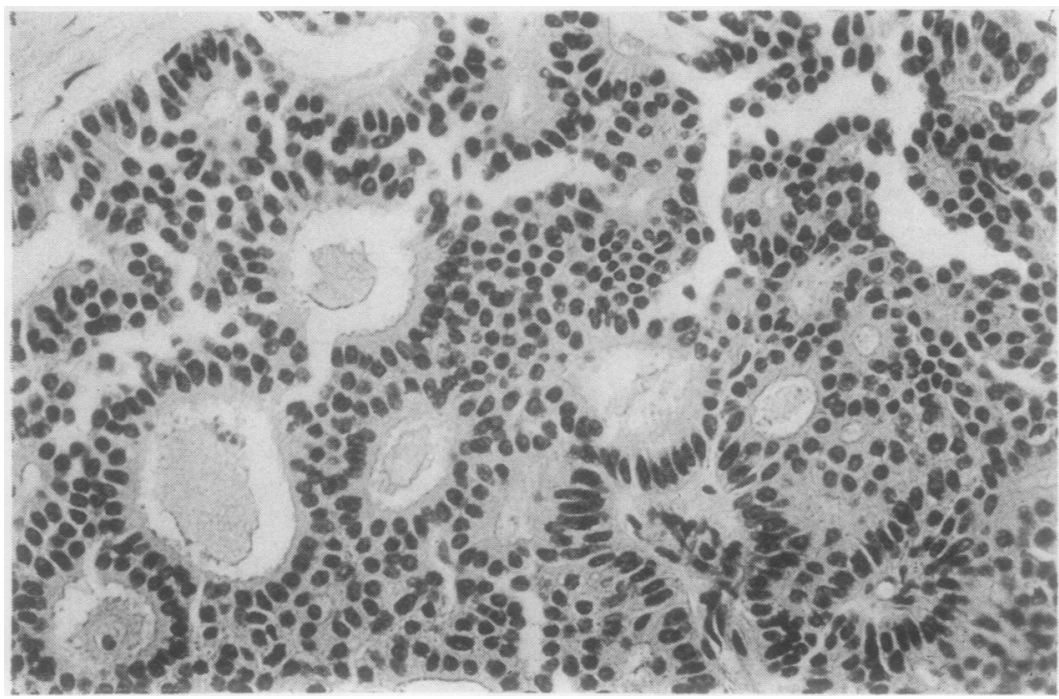

Fig 9 Detail of cribriform intraduct carcinoma (Haematoxylin-eosin $\times 138)$. 
Individual tumour cells were larger with variable nuclei, a more open chromatin pattern, and often prominent nucleoli. The cytoplasm was more abundant and finely granular. The cells tended to show a polar arrangement around duct-like or cystic lumina which contained mucus (fig 9). Mitoses and areas of necrosis were frequently present. They stained positively with both alcian blue and PAS, and in combined preparations, with PAS rather than with alcian blue (table III). No immunofluorescent staining was obtained with anti-actomyosin serum in the two cases tested.

\section{'BASALOID' TUMOURS}

Four tumours consisted of lobulated masses with a cribriform pattern but lacked other criteria considered necessary for the diagnosis of adenocystic carcinoma. The tumour cell masses were much more disorderly, and the individual cells were more pleomorphic and lacked a biphasic pattern with small duct-like structures (fig 10). The 'cysts' stained only with alcian blue (table III). Occasional

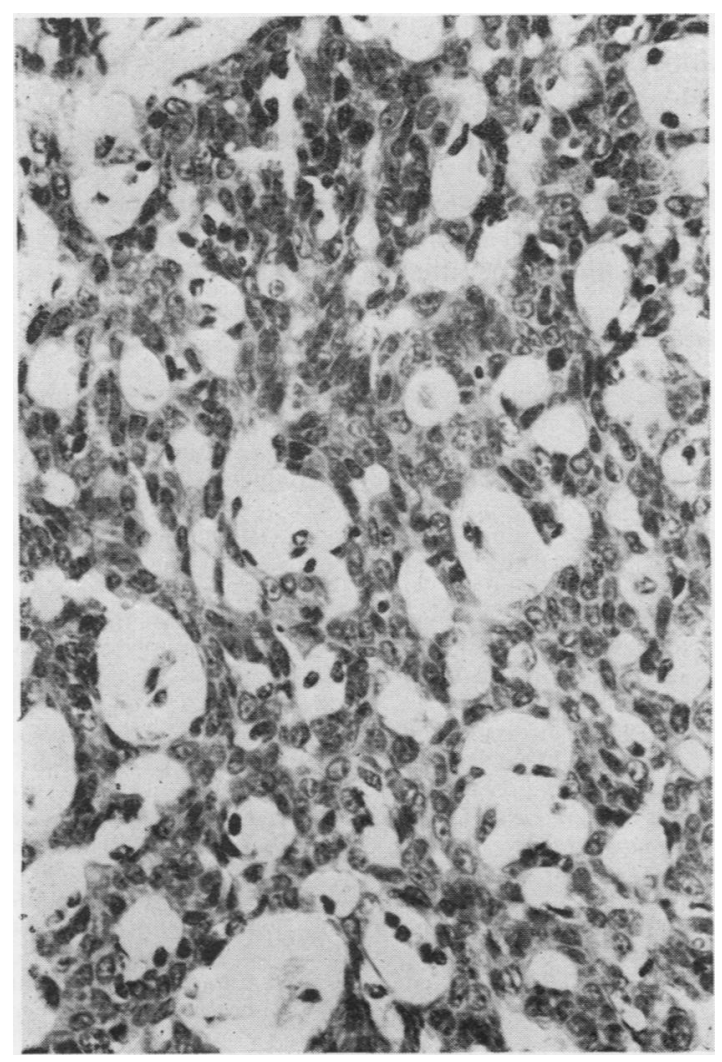

Fig 10 Cribriform pattern of a 'basaloid' tumour. Note the disorderly arrangement and marked nuclear pleomorphism (Haematoxylin-eosin $\times 138)$. flecks of immunofluorescence to actomyosin were seen but were not considered significant. It is possible that these 'basaloid' tumours (so designated because of their similarity to basal or myoepithelial cells) do, in fact, represent a more malignant or, at any rate, less well differentiated variant of adenoid cystic carcinoma, but this could not be established with certainty and these tumours should remain classified with 'ordinary' adenocarcinoma of the breast.

\section{Discussion}

Nearly a hundred cases of adenoid cystic carcinoma of the breast have been reported in the world literature to date, most of them in the last five years. Table I summarizes some salient features. The age range and the average age of patients are not distinctive. It is a tumour affecting almost exclusively women though two examples in men have been recorded (Woyke et al, 1970; Verani and van der Bel-Kahn, 1973). The duration of symptoms is variable but often quite long - months or even many years. It is worth noting that Lusted (1970) had calculated the linear growth rate of the tumour in one case as $2.4 \mathrm{~mm}$ per year. Presentation is generally with a mass in the breast. In four of the nine cases reported by Galloway et al (1966) the lump was painful and/or tender. Cavanzo and Taylor (1969) comment on their 21 cases that 'the main presenting symptom was a mass in the breast, sometimes tender'. Pain or tenderness was also reported by Friedman and Oberman (1970), Lusted (1970), and Hopkins and Tullis (1972). This was also the case in two of our three patients. The tumour often arises in the nipple area (Galloway et al, 1966; Friedman and Oberman, 1970; Hopkins and Tullis, 1972; Verani and van der Bel-Kahn, 1973). This was so in two of our three cases. The size of the tumour is generally 1 to $3 \mathrm{~cm}$, though it occasionally is much larger. Macroscopically it presents as a fairly well defined, sometimes lobulated mass which may be grossly cystic.

The prognosis of daenoid cystic carcinoma of the breast is much better than that of similar tumours elsewhere in the body. Nearly one-third of the patients with tumours at other sites have regional or distant metastases at the time of first presentation, and local recurrence followed by further spread is common; five-year survival, on average, is about $30 \%$ (Cavanzo and Taylor, 1969). By contrast, there are very few instances where daenoid cystic carcinoma of the breast has shown a similarly aggressive behaviour. Local recurrence has been recorded in only four cases (Wilson and Spell, 1967; Cavanzo and Taylor, 1969; Lusted, 1970) and metastases in 
only five (Nayer, 1957; O'Kell, 1964; Elsner, 1970; Verani and van der Bel-Kahn, 1973) of which two are incompletely documented (Nayer, 1957; O'Kell, 1964). Several authors have advocated local excision or at most simple mastectomy as adequate treatment. Certainly, in one case only has regional lymph node metastasis been found (Verani and van der Bel-Kahn, 1973), and axillary dissection would seem superfluous.

At the outset of this 10-year review of breast tumours it was expected that a number of adenoid cystic carcinomas might be found which had been misdiagnosed. This has not turned out to be the case: only three unequivocal examples were identified. The risk lies not in failure to recognize but in overdiagnosis, which may be stimulated by numerous recent reports. Strict criteria must be used in differential diagnosis, particularly from cribriform intraduct carcinoma which has also been emphasized by Galloway et al (1966), Friedman and Oberman (1970), and Lusted (1970). This can be achieved by examination of routine sections stained with haematoxylin-eosin alone, but the demonstration of acid mucopolysaccharides in 'cysts' and of neutral mucopolysaccharides in small duct-like lumina is of additional help. We believe that the 'cysts' represent invaginations of young connective tissue stroma, and this has been previously established by serial sectioning of whole tumours (Lusted, 1970) and by electron microscopy (Koss et al, 1970). The main mass of the tumour consists of myoepithelial cells producing acid mucopolysaccharides and fibrillary connective tissue while the scanty duct-like structures probably represent differentiation towards mammary duct epithelium, capable of secreting PAS-positive mucus. This, again, is supported by previous reports on ultrastructure (Eneroth et al, 1968; Murad and von Haam, 1968; Koss et al, 1970). We consider this biphasic cellular pattern to be the most important single diagnostic criterion of adenoid cystic carcinoma.

The identity of 'basaloid' tumours remains in doubt. We feel that tumours with such appearances should be iegarded as variants of 'ordinary' adenocarcinoma unless evidence to support a myoepithelial origin can be found. We have not been able to demonstrate actomyosin in two of four cases.

The histogenesis of adenoid cystic carcinoma is of interest in view of its biphasic histological pattern and distinctive clinical behaviour. The cytological features suggest that it originates from myoepithelial cells, but it also has a secretory, ductal element, and electron microscopy studies have shown evidence of both types of cell. The interpretation of ultrastructural appearances has given rise to some controversy between those who favour a pre- dominantly ductal epithelial or a predominantly $\stackrel{\text { 劣 }}{\Rightarrow}$ myoepithelial origin (Koss et al, 1970). Filamentous $\stackrel{\vec{\rho}}{+}$ material resembling myofibrils has also been demonstrated with phosphotungstic acid-haematoxylin (Friedman and Oberman, 1970), but we $\frac{\bar{\rho}}{\vec{\alpha}}$ have not been able to confirm this.

Immunological studies on tissue sections are usually performed on fresh frozen, unfixed or cold ${ }_{\vec{\omega}}$ alcohol-fixed, paraffin-embedded material (Sainte-. Marie, 1962). Recent reports, however, have shown $\overrightarrow{\vec{\omega}}$ that an increasing amount of immunological work is $\stackrel{\omega}{\rho}$ being performed on routine, formalin-fixed, paraffin- $\bar{\theta}$ embedded material. A study on intracellular i immunoglobulins comparing three standard tissue ${ }_{\infty}^{\infty}$ processing methods showed that immunofluorescence $o$ from formalin-fixed, paraffin-embedded tissues $\stackrel{\nexists}{v}$ compared favourably with that obtained using 의 either fresh frozen or the Sainte-Marie method of tissue preservation (Burns et al, 1974). We have similarly not experienced any difficulty in demonstrating actomyosin by immunofluorescence in $\stackrel{\infty}{\stackrel{\oplus}{\leftrightarrow}}$ routinely processed tissues.

The demonstration of myofibrils in our three ov cases of adenoid cystic carcinoma using specific antiserum to actinomyosin and an indirect immuno-o fluorescent technique is strong evidence of a myoepithelial origin of these tumours. The presence of myofibrils by immunofluorescent methods has not $\frac{\square}{D}$ been reported previously. We would further suggest $\propto$ that pain and tenderness may also be caused by a $\overrightarrow{\overrightarrow{0}}$ contractile, myoepithelial component.

\section{References}

Burns, J., Hambridge, M., and Taylor, C. R. (1974). Intracellular immunoglobulins: a comparative study on three $\bar{\sigma}$ standard tissue processing methods using horseradish peroxidase and fuorochrome conjugates. J. clin. Path., $\delta$ 27, 548-557.

Cavanzo, F. J. and Taylor, H. B. (1969). Adenoid cystic carcinoma of the breast. An analysis of 21 cases. Cancer음 (Philad.), 24, 740-745.

Elsner, B. (1970). Adenoid cystic carcinoma of the breast. Review of the literature and clinico-pathologic study of seven patients. Path. europ., 5, 357-364.

Eneroth, C. M., Hjertman, L., Moberger, G., and Wersäll, J. (1968). Ultrastructural characteristics of adenoid cystic $N$ carcinoma of salivary glands. Arch. Klin. Exp. Ohr.-, Nas.-, N Kehlk.-Heilk., 192, 358-368.

Evans, R. W. and Cruickshank, A. H. (1970). Epithelia Tumours of the Salivary Glands. Saunders, Philadelphiao and London.

Friedman, B. A. and Oberman, H. A. (1970). Adenoid@ cystic carcinoma of the breast. Amer. J. clin. Path., 54; 1-14.

Galloway, J. R., Woolmer, L. B., and Clagett, O. T. (1966) $\frac{\bar{D}}{(\bar{D}}$ Adenoid cystic carcinoma of the breast. Surg. Gynec. Obstet., 122, 1289-1294.

Hopkins, G. B. and Tullis, R. H. (1972). Adenoid cystic carcinoma of the breast. Calif. Med., 117 (4), 9-11.

Koss, L. G., Brannan, C. D., and Ashikari, R. (1970) Histologic and ultrastructural features of adenoid cystiog 
carcinoma of the breast. Cancer (Philad.), 26, 1271-1279.

Lusted, D. (1970). Structural and growth patterns of adenoid cystic carcinoma of breast. Amer. J. clin. Path., 54, 419-425.

Mowry, R. W. (1956). Alcian blue technics for the histochemical study of acidic carbohydrates. J. Histochem. Cytochem., 4, 407.

Murad, T. M., and von Haam, E. (1968). Ultrastructure of myoepithelial cells in human mammary gland tumors. Cancer (Philad.), 21, 1137-1149.

Nayer, H. R. (1957). Cylindroma of the breast with pulmonary metastases. Dis. Chest., 31, 324-327.

O'Kell, R. T. (1964). Adenoid cystic carcinoma of the breast. Missouri Med., 61, 855-858.

Sainte-Marie, G. (1962). A paraffin embedding technique for studies employing immunofluorescence. J. Histochem. Cytochem., 10, 250-256.

Thackray, A. C. and Sobin, L. H. (1972). Histological Typing of Salivary Gland Tumours (International Histological Classification of Tumours, No. 7). WHO, Geneva.

Verani, R. R. and van der Bel-Kahn, J. (1973). Mammary adenoid cystic carcinoma with unusual features. Amer. J. clin. Path., 59, 653-658.

Wilson, W. B. and Spell, J. P. (1967). Adenoid cystic carcinoma of breast: a case with recurrence and regional metastases. Ann. Surg., 166, 861-864.

Woyke, S., Domagala, W., and Olszewski, W. (1970). Fine structure of mammary adenoid cystic carcinoma. Pol. med. J., 9, 1140-1148.

\section{The July 1975 Issue}

\section{THE JULY 1975 ISSUE CONTAINS THE FOLLOWING PAPERS}

Neutrophil alkaline phosphatase score in chronic granulocytic leukaemia: effects of splenectomy and antileukaemic drugs A. S. D. SPIERS, A. LIEW, AND A. G. BAIKIE

Simple screening tests for the diagnosis of isolated clotting factor defects G. I. C. INGRAM, S. F. KNIGHTS, C. L. AROCHA-PIÑANGO, J. P. SHEPPERD, J. L. PÉREZ-REQUeJO, AND D. K. MILLS

Extraction of serum vitamin $\mathrm{B}_{12}$ for radio-isotopic and Lactobacillus leichmannii assay J. L. RAVEN AND M. B. ROBSON

An automated immunoradiometric assay for ferritin B. M. JONES AND M. WORWOOD

A study of immunoglobulin $\mathbf{M}$ antibody to measles, canine distemper, and rinderpest viruses in sera of patients with subacute sclerosing panencephalitis DOROTHY THOMSON, J. H. CONNOLLY, B. O. UNDERWOOD, AND F. BROWN

Sensitivity of some human pathogenic yeasts and systemic fungi to myxin AWATER S. SEKHON AND ERIKA HARGESHEIMER

Interaction in vitro between synovial cells and autologous lymphocytes and sera from arthritis patients T. GHOSE, J. F. WOODBURY, AND M. M. HANSELL

Liver disease in infancy: histological features and relationship to $\alpha_{1}$-antitrypsin phenotype I. C. TALBOT AND A. P. MOWAT
Injury and repair of tracheobronchial cartilage following accidental exposure to ethyleneimine G. A. GRESHAM AND I. E. WEST

Myocardial lysis in acute rheumatic fever followed by regeneration of cardiac muscle and origin of Aschoff bodies HEMPROVA GHOSH MCDONALD

Bilateral fibrosarcoma of the epididymis MALCOLM MCCORMACK

Use of a computer for producing microbiological reports and for data storage and processing J. L. FARRAR, T. D. BROGAN, T. MOULDING, R. TAYLOR, AND M. PAGE

Evaluation and utilization of a kinetic enzyme direct measuring photometer PAUL L. WOLF

Revised list of abbreviations for names of enzymes of diagnostic importance D. N. BARON, D. W. MOSS, P. G. WALKER, AND J. H. WILKINSON

\section{Technical methods}

Staining of the A antigen on human erythrocytes D. Y. MASON AND C. R. TAYLOR

Preparation of 'contact product' as a reagent for coagulation tests J.-L. PÉREZ-REQUEJo AND G. I. C. INGRAM

Letters to the Editor

Book reviews

Copies are still available may be obtained from the PUBLISHING MANAGER, BRITISH MEDICAL ASSOCIATION, TAVISTOCK SQUARE, LONDON WC1H 9JR, price $£ 2.00$ 